\section{Correlation Between Radiographic Area and Immunolocation of MMP-2 and MMP-9 in Unilocular Radiographic Lesions}

Rafaela Scariot ${ }^{1}$, Lucas Caetano Uetanabaro ${ }^{1}$, Melissa Rodrigues de Araujo ${ }^{1}$, Joao Zielak', Allan Fernando Giovanini', Delson João da Costa ${ }^{2}$, Nelson Luis Barbosa Rebellato2 ${ }^{2}$ Renato Cordeiro Gugisch ${ }^{2}$
'Graduate Program in Dentistry, Positivo University, Curitiba, PR, Brazil ${ }^{2}$ Graduate Program in Dentistry, UFPR - Federal University of Paraná, Curitiba, PR, Brazil

Correspondence: Dra. Rafaela Scariot de Moraes,

Rua Deputado Heitor Alencar Furtado, 3180 Ap 13W 81200-110 Curitiba, PR, Brasil. Tel.: +055-41-3285-9394. e-mail: rafaela_scariot@yahoo.com.br

\begin{abstract}
Unilocular bone cysts are the most common entities affecting the maxillofacial region. The mechanism of proliferation and expansion remains unclear. Metalloproteinases (MMPs) are associated to diverse pathological conditions. The aim of the present study was to correlate the radiographic aspect (area) and the presence of MMP-2 and MMP-9 in dentigerous cysts, radicular cysts and keratocystic odontogenic tumors. The radiographic area of each lesion was calculated using the mathematical formula of the ellipse area. All specimens were subjected to immunohistochemical analysis for these enzymes. The average radiographic area was $284.17 \mathrm{~mm}^{2}, 235.81 \mathrm{~mm}^{2}$ and $381.81 \mathrm{~mm}^{2}$, respectively. Statistical analyses revealed no association between the immunoreactivity of MMPs and radiographic area of the lesions in all pathologies studied, except for MMP-2 and radicular cysts, for which smaller lesions had increased immunostaining for this enzyme. The results demonstrate that quantities of MMP-2 and MMP-9 are especially involved with dentigerous and radicular cysts in expansion, whereas these enzymes seem to be related to the biological behavior of keratocystic odontogenic tumors, indicating invasion and cell proliferation. Moreover, there is an inverse association between MMP-2 and MMP-9 in keratocystic odontogenic tumors ( $\left.p=0.03 ; r_{s}=-0.660\right)$, indicating activity in different regions.
\end{abstract}

Key Words: jaw cysts, metalloproteins, radiography.

\section{Introduction}

Cysts are developmental, inflammatory or neoplastic disorders presenting as a pathological cavity with its lumen filled with liquid or semi-solid material lined with epithelium surrounded by a rich stroma forming a capsule (1). Lesions that exhibit this architectural pattern are the most common form of intraosseous pathological entities that affect the maxillofacial region (2). From the epidemiological standpoint, the most frequent lesions exhibiting these patterns are radicular cysts (RC), dentigerous cysts (DC) and keratocystic odontogenic tumors (KCOT) (3).

A number of studies have demonstrated the importance of the proliferation and expansion potential of these entities and consequent osteolysis. These factors are generally associated to the synthesis of proteins or enzymes that modify the homeostasis of the cystic epithelium and extracellular matrix (ECM), particularly in KCOTs (4).

Metalloproteinases (MMPs) are proteolytic, zincdependent enzymes secreted by epithelial and conjunctival cells that play an important role in a number of physiological and pathological conditions, such as tissue remodeling and cell invasion cellular (5-7). MMPs are classified based on their structure and the specificity of their substrates. MMP2 (72 kDa) and MMP-9 (92 kDa) are gelatinases and play specific roles in the degradation of ECM macromolecules. These enzymes contain three repetitions of a fibronectin II domain in their catalytic domain, which aid in the degradation of type IV collagen, gelatins and elastin (8). Thus, MMP-2 and MMP-9 are correlated to mesenchymal cell differentiation, proliferation and migration, enhanced collagen affinity, anti-inflammatory activity, reduced Interleukin-2 response and other processes (8). When out of balance, these biological processes can influence the behavior of some pathology, especially in intrabony lesions.

The aim of the present study was to correlate radiographic aspects and immunopositivity for MMP-2 and MMP-9 in DCs, RCs and KCOTs.

\section{Material and Methods \\ Sample Selection}

The histopathological specimens of patients having undergone biopsy at the Dental School of the Federal University of Paraná, Brazil between 2005 and 2009, with a confirmed diagnosis of DC, RC or KCOT were selected. Besides the histopathological material, panoramic radiographs performed at the same institution prior to treatment were also part of the inclusion criteria. The study received approval from the ethics committee of the 
institution under process number CAAE 00350091000-09.

\section{Radiographic Analysis}

All panoramic radiographs were analyzed on an Ortophos $\mathrm{CD}^{\circledR}$ orthopantomograph (Siemens, Berlin, Germany) at the Department of Dental Radiology of the institution. As all lesions studied were unilocular, the area of each lesion was measured. For such, the principal axes (Axis 1: height; Axis 2: length) were measured in millimeters using a digital caliper (Vonder, Curitiba, PR, Brazil). These measurements corresponded to the diameters of the lesions, which had an elliptical shape. Radiographic interpretation of each lesion was performed three different times at 2-week intervals by a single calibrated examiner in a dark room with a proper light box. Measurements obtained on each axis were tabulated and statistically evaluated as to their reliability using the intraclass correlation coefficient with a 95\% confidence interval. The average of the each axis value was subtracted from a predetermined magnification value of the panoramic radiograph in order to obtain the actual measurement of the lesion in two dimensions. The area of each lesion was calculated in $\mathrm{mm}^{2}$ using a mathematical formula [area of ellipsis $=\pi$ $x$ radius 1 (Axis 1/2) $\times$ radius 2 (Axis 2/2]

\section{Immunohistochemistry Procedure}

Cuts three micrometers in thickness of each specimen were deparaffinized and submitted to antigen retrieval in $1 \mathrm{~N}$ trypsin solution ( $\mathrm{pH}$ 7.2) for 60 min at $37^{\circ} \mathrm{C}$. The slides containing the histological specimens were immersed in 3\% hydrogen peroxide for $30 \mathrm{~min}$ to extinguish endogenous peroxidase activity, followed by incubation with $1 \%$ phosphate-buffered saline (pH 7.4). The sections were incubated overnight with the primary antibody anti-MMP2 (NCL-MMP-2-507 - Mouse Monoclonal; Novocastra ${ }^{\oplus}$, Leica Biosystems Newcastle Ltd, UK) and anti-MMP9 (NCLMMP-9-439 - Mouse Monoclonal; Novocastra ${ }^{\circledR}$ ), both with dilution factor of 1:20. The labeled streptavidin biotin (AdvanceTM HRP Label - Link and Enzyme - K4068; Dako ${ }^{\circledR}$, Glostrup, Germany) antibody-binding detection system was used to detect the primary antibodies. The immunoreaction was revealed with 3,3' diaminobenzidine tetrachloride (Sigma, St. Louis, MO, USA) for $3 \mathrm{~min}$, producing a brown precipitate at the antigen site. The specimens were counterstained with Harris hematoxylin. For each specimen, three slides were used for incubation with each antibody.

\section{Immunohistochemical Analysis}

MMP-2 and MMP-9 immunoreactivity was determined
Table 1. Partial measures and final area obtained for each lesion

\begin{tabular}{|c|c|c|c|c|c|}
\hline $\begin{array}{l}\text { Odontogenic } \\
\text { Pathology }\end{array}$ & $\begin{array}{l}\text { Mean } \\
\text { Axis } 1 \\
(\mathrm{~mm})\end{array}$ & $\begin{array}{l}\text { Mean } \\
\text { Axis } 2 \\
(\mathrm{~mm})\end{array}$ & $\begin{array}{c}\text { Mean Axis } 1 \\
\text { subtracted to } \\
\text { magnification (mm) }\end{array}$ & $\begin{array}{c}\text { Mean Axis } 2 \\
\text { subtracted to } \\
\text { magnification }(\mathrm{mm})\end{array}$ & $\begin{array}{l}\text { Final Area } \\
\text { of Lesion } \\
\left(\mathrm{mm}^{2}\right)\end{array}$ \\
\hline \multirow{10}{*}{$\begin{array}{l}\text { Dentigerous } \\
\text { Cyst } \\
\text { 1CC: } 0.991\end{array}$} & 27.69 & 27.16 & 20.51 & 20.12 & 323.93 \\
\hline & 17.86 & 21.34 & 13.66 & 16.32 & 175 \\
\hline & 11.84 & 12.79 & 10.22 & 11.04 & 88.57 \\
\hline & 14.59 & 17.64 & 12.59 & 15.22 & 150.30 \\
\hline & 15.33 & 18.66 & 13.23 & 16.01 & 166.27 \\
\hline & 13.56 & 23.63 & 11.70 & 20.39 & 187.27 \\
\hline & 18.77 & 18.98 & 13.90 & 14.06 & 153.41 \\
\hline & 48.65 & 47.26 & 41.99 & 40.79 & 1344.20 \\
\hline & 22.18 & 15.89 & 16.97 & 12.15 & 161.76 \\
\hline & 10.18 & 19.49 & 7.78 & 14.91 & 91.05 \\
\hline \multirow{9}{*}{$\begin{array}{l}\text { Radicular } \\
\text { Cyst } \\
\text { 1CC: } 0.996\end{array}$} & 35.08 & 24.42 & 30.28 & 21.08 & 501.06 \\
\hline & 14.01 & 15.20 & 12.09 & 13.12 & 124.41 \\
\hline & 12.49 & 12.97 & 10.78 & 11.19 & 94.69 \\
\hline & 33.27 & 20.86 & 28.72 & 18.00 & 405.81 \\
\hline & 23.69 & 15.88 & 20.45 & 13.70 & 219.82 \\
\hline & 37.27 & 24.82 & 32.17 & 21.42 & 540.76 \\
\hline & 12.03 & 20.79 & 10.38 & 17.94 & 146.18 \\
\hline & 11.55 & 11.35 & 8.55 & 8.40 & 56.31 \\
\hline & 10.44 & 6.95 & 7.98 & 5.31 & 33.26 \\
\hline \multirow{8}{*}{$\begin{array}{l}\text { Keratocystic } \\
\text { Odontogenic } \\
\text { Tumor } \\
\text { 1CC:0.987 }\end{array}$} & 33.23 & 30.49 & 24.61 & 22.58 & 436.04 \\
\hline & 21.31 & 17.37 & 18.39 & 14.99 & 216.28 \\
\hline & 35.15 & 34.86 & 26.91 & 26.67 & 563.17 \\
\hline & 19.28 & 18.85 & 16.64 & 16.27 & 212.52 \\
\hline & 13.07 & 14.72 & 10.00 & 11.26 & 88.39 \\
\hline & 43.14 & 26.47 & 33.01 & 20.25 & 524.57 \\
\hline & 19.31 & 18.23 & 14.77 & 13.94 & 161.51 \\
\hline & 48.45 & 40.84 & 35.89 & 30.25 & 852.01 \\
\hline
\end{tabular}

ICC: Intraclass coefficient correlation. 
qualitatively (descriptive) and quantitatively. All sections were examined under a light microscope at magnifications of $\times 40$ and $\times 100$. Two evaluators analyzed the presence or absence of immunoreactivity to the proteases, characterizing the reaction as (-) negative, $(+)$ positive or $(++)$ strongly positive, based on Kumamoto et al..(9)

\section{Statistical Analysis}

The results were submitted to statistical analysis. Computations were made using the Statistical Package for the Social Sciences ${ }^{\circledR}$ (version 15.0; SPSS Inc., Chicago, IL, USA). The association of the variables (immunostaining and area of lesion) was determined using Spearman's rank correlation coefficient, with the significance level set at $5 \%(\mathrm{p}<0.05)$.

\section{Results}

Based on the eligibility criteria, the sample was composed 10 DCs, 9 CRs and 8 KCOTs.

\section{Radiographic Analyses}

All lesions examined had a unilocular radiographic appearance. The mean length $(\mathrm{mm})$ of Axis 1 and Axis 2 was determined for the morphometric radiographic analysis. The $\vec{s}$ intraclass coefficient correlation (ICC) was determined for each value and proved to be a useful tool. Magnification of the image was $13.67 \%$ for the region of the incisors and canines, 25.92\% for the region of the premolars and $23.48 \%$ for the region of the molars. The mean area of the DCs, RCs and KCOTs was $284.17 \mathrm{~mm} 2,235.81 \mathrm{~mm} 2$ and $381.81 \mathrm{~mm} 2$, respectively (Table 1).

\section{Immunohistochemical Analyses}

A detailed description of the qualitative data is described below, while the quantitative results are displayed in Tables 2 and 3.

MMP-2: In dentigerous and radicular cysts, MMP-2 was present in the entire cystic capsule, with greater positivity on the edge of the capsule adjacent to the remaining bone tissue (Figs. 1A, 1B and 1C). In radicular cysts, besides the

Table 2. Description of the quantitative data of the immunohistochemistry to MMP-2

\begin{tabular}{|c|c|c|c|c|c|c|}
\hline & \multicolumn{6}{|c|}{ MMP-2 } \\
\hline & \multicolumn{2}{|c|}{ DC } & \multicolumn{2}{|c|}{$\mathrm{RC}$} & \multicolumn{2}{|c|}{ KCOT } \\
\hline & $n$ & $(\%)$ & $\mathrm{n}$ & $(\%)$ & $n$ & $(\%)$ \\
\hline- & 2 & 20 & 4 & 44.4 & 3 & 37.5 \\
\hline+ & 5 & 50 & 3 & 33.3 & 2 & 25.0 \\
\hline++ & 3 & 30 & 2 & 22.3 & 3 & 37.5 \\
\hline Total & 10 & $100 \%$ & 9 & $100 \%$ & 8 & $100 \%$ \\
\hline
\end{tabular}

region of bone edge, there was also MMP-2 immunostaining in areas of chronic inflammation and overlapping areas in the region in which epithelial projections were evident (Fig. 1D). In contrast, KCOTs exhibited immunopositivity to MMP-2 particularly adjacent to cystic epithelium in loci in which the interaction between the epithelium and connective tissue was lost (Figs. 1E and 1F).

MMP-9: Immunolocalization of MMP-9 in DCs and $\mathrm{RCs}$ presented a similar pattern, occurring mainly in the epithelium and randomly in the cystic capsule (Figs. 2A, $2 \mathrm{~B}, 2 \mathrm{C})$. The RCs exhibited greater immunostaining in inflammatory areas (Fig. 2D). The KCOTs had larger and stronger areas positive to MMP-9, which was expressed in both the capsule and epithelium (Figs. 2E and 2F).

\section{Correlation between Immunostaining of MMPs and Radiographic Appearance}

No associations were found between the immunostaining and the area of radiographic lesions, except for an inverse correlation between MMP- 2 and RCs $\left(p=0.02 ; r_{s}=-0.659\right)$, for which smaller lesions had increased immunostaining for this enzyme. The samples of all lesions were divided into two groups based on the mean area of the lesions: greater than $200 \mathrm{~mm}^{2}$ and smaller than $200 \mathrm{~mm}^{2}$. For lesions smaller than $200 \mathrm{~mm}^{2}$, there was an inverse association between lesion size and immunoreactivity $\left(p=0.013 ; r_{s}=-0.593\right)$. Moreover, in the KCOTs, there was an inverse association between MMP-2 and MMP-9 $\left(p=0.03 ; r_{s}=-0.660\right)$.

\section{Discussion}

Cystic entities are found in a wide range of developmental, inflammatory and neoplastic diseases and are composed of epithelial tissue surrounding a cavity linked to a capsule composed of connective tissue (1). Despite the similar microarchitecture, significant epidemiological, behavioral and biological differences are found in these pathologies.

In the radiographic analysis, all lesions revealed a unilocular aspect associated with a sclerotic halo, with

Table 3. Description of the quantitative data of the immunohistochemistry to MMP-9

\begin{tabular}{|c|c|c|c|c|c|c|}
\hline & \multicolumn{6}{|c|}{ MMP-9 } \\
\hline & \multicolumn{2}{|c|}{ DC } & \multicolumn{2}{|c|}{$\mathrm{RC}$} & \multicolumn{2}{|c|}{ KCOT } \\
\hline & $\mathrm{n}$ & $(\%)$ & $n$ & $(\%)$ & $\mathrm{n}$ & $(\%)$ \\
\hline - & 4 & 40 & 1 & 11.2 & 1 & 12.5 \\
\hline+ & 4 & 40 & 4 & 44.4 & 1 & 12.5 \\
\hline++ & 2 & 20 & 4 & 44.4 & 6 & 75.0 \\
\hline Total & 10 & $100 \%$ & 9 & $100 \%$ & 8 & $100 \%$ \\
\hline
\end{tabular}


the latter finding only constant among dentigerous and radicular cysts. The mean size was different between the pathological entities. KCOTs were larger in comparison with other cysts studied, which is consistent with findings described in the literature (3). The mean size of the dentigerous and radicular cysts was $284.17 \mathrm{~mm} 2$ and $235.81 \mathrm{~mm} 2$, respectively. Although the mean size of the DCs and RCs was greater than $200 \mathrm{~mm} 2,13$ of these cysts $(68.42 \%)$ had areas smaller than $200 \mathrm{~mm} 2$. These cysts had an inverse correlation between lesion area and immunopositivity for both MMP-2 and MMP-9, with smaller DCs and RCs exhibiting greater immunoreactivity to these enzymes. These data suggest greater enzyme activity in the earlier development stages of these cysts, providing further degradation of ECM components.

In all specimens of DCs and RCs smaller than $200 \mathrm{~mm} 2$, the results indicate that the presence of MMP-2 was intense and coincided with the edges adjacent to bone. These results corroborate previous studies describing the importance of this enzyme in the process of cystic expansion $(10,11)$. The present study also reveals that, in the early stages of the lesion, MMP-2 not only digests denatured collagen
I more slowly, but may also be responsible for inducing the formation of the sclerotic rim in DCs and RCs. This hypothesis is supported by findings described by Sakamoto et al. (12), who demonstrated the presence of calcification associated with an increased amount of MMP-2, suggesting a direct association between calcium deposition and ECM degradation (12). The authors point out that there are no specific markers for bone lineage in this process, confirming that calcification associated to MMP-2 is not secondary to ossification, but rather the deposition of a pathological form of calcium. In the present study, this phenomenon also occurred in six DCs and RCs with a mean area larger than $200 \mathrm{~mm} 2$.

Comparing only the immunoexpression of MMP-2 in the DCs and RCs, scores were higher in the former. With respect to the immunostaining of MMP-2 and RCs, there was a prevalence of this enzyme in the mesenchyme, mainly associated with inflammatory cells and areas coinciding with the formation of epithelial projections. Statistically, there was an inverse correlation between lesion area and immunostaining in the cyst, which may mean that the inflammatory process is greater in immature lesions of
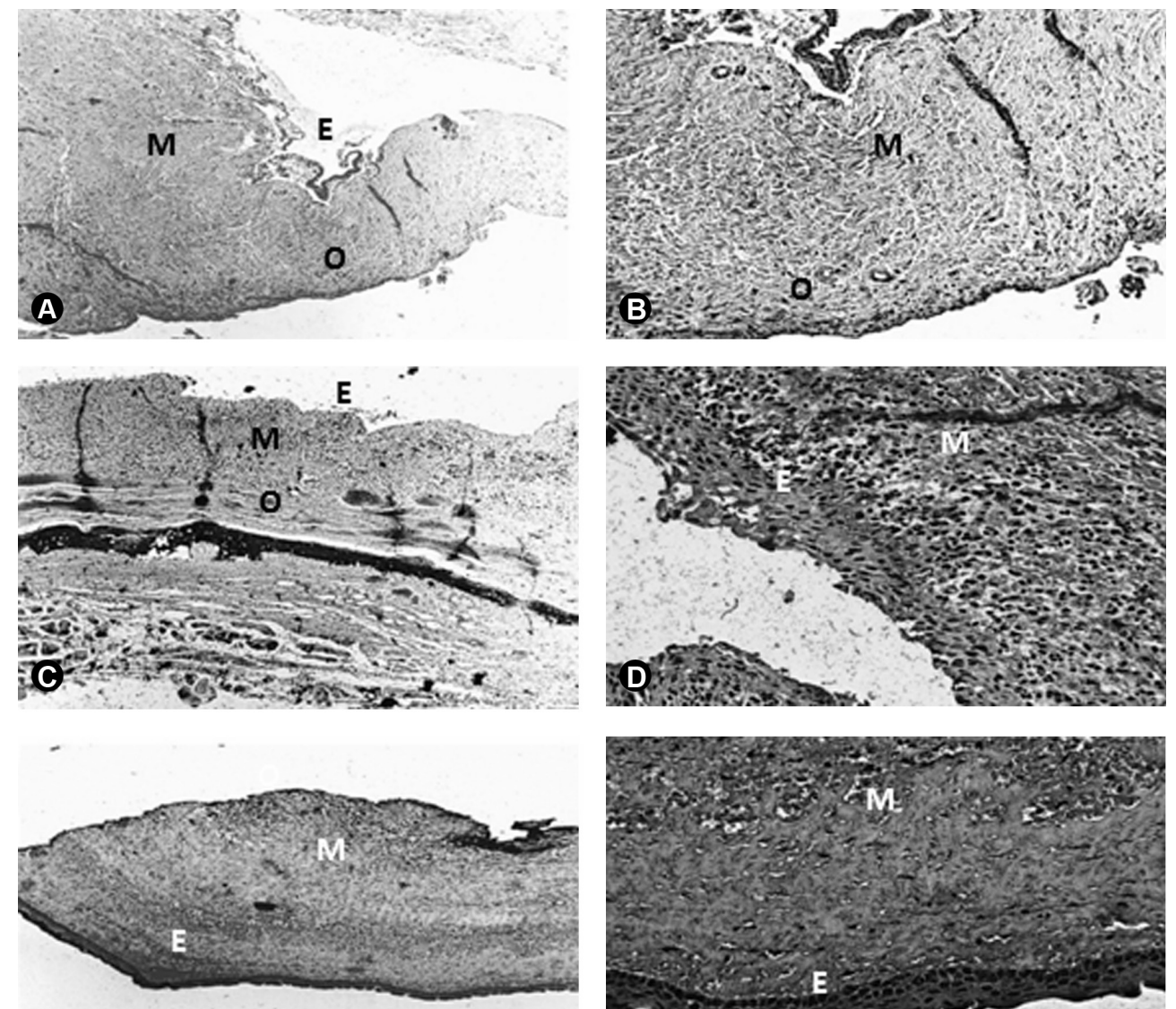

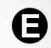

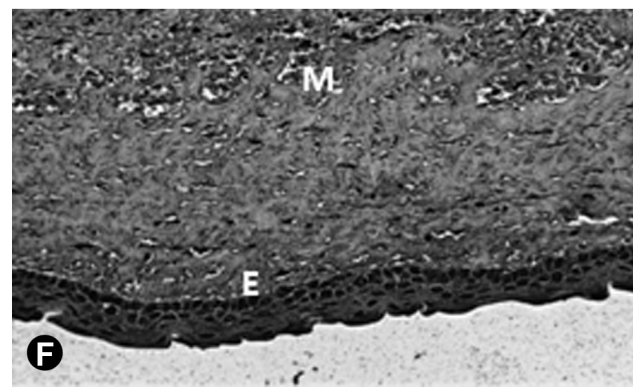

Figure 1. Board of histological slides with the immunostaining for MMP-2 in DC (A and B), RC (C and D) and KCOT (E and F), in 40x and 100x. 
an endodontic origin than mature lesions. It is suggested that MMP-2 in RCs triggers a chain of osteolytic events, stimulated initially by cells in the inflammatory process. MMP-9 was also found in most of the cystic capsule of the DCs and RCs, again linking this enzyme to expansion.

In the KCOTs, intense expression of MMP-2 and MMP-9 was found in the epithelium and mesenchyme. Although odontogenic tumors have a keratocystic immunostaining score similar to that of DCs, the location of MMP-2 in KCOTs is different. This enzyme occurred throughout the entire conjunctive capsule, indicating greater osteolytic action in the capsule in comparison to developmental cysts. The presence of IL-1 $\alpha$ in cyst fluid of the KCOTs may help in understanding this result. Teronen et al. (13) and Meghii et al. (14) found that levels of IL-1 $\alpha$ are significantly higher in the cyst fluid of keratocystic odontogenic tumors than that of other cysts. $0 \mathrm{ka}$ et al. found that the positive pressure of the fluid induced bone resorption in KCOTs, since the increased expression of IL-1 $\alpha$ induces the secretion of MMP-1, MMP-2 and MMP-3, which are responsible for bone resorption (15).

Moreover, MMP-2 is known to have an affinity for laminin and type IV collagen, which are the main constituents of the basal lamina (16). This indicates that MMP-2 may be related to the breakdown of the basal lamina, inducing the process of tumor invasion of the epithelium for the formation of offspring or satellite cysts. This appears to have occurred in the specimens analyzed in the present study, as labeling for MMP-2 was found in the basal lamina region of the epithelium and primary cystic areas suggestive of offspring cysts.

An interesting finding was that regions with immunostaining for MMP-2 revealed no expression of MMP-9, suggesting that MMP-2 plays a different role from that of MMP-9, despite their similar structural conformation and its regulatory power over MMP-9, which makes it inactive. In the KCOT specimens studied here, it may be suggested that the intense presence of MMP-9 occurred due to the regulatory inefficiency of MMP-2, as occurs in neoplastic alterations (17). Thus, although MMP9 is immunolabeled in different areas of MMP-2, it was more intense than MMP- 2 in the KCOTs, indicating that the presence of MMP-9 is related not only to cystic expansion, but also to the aggressiveness of the lesion. Confirming
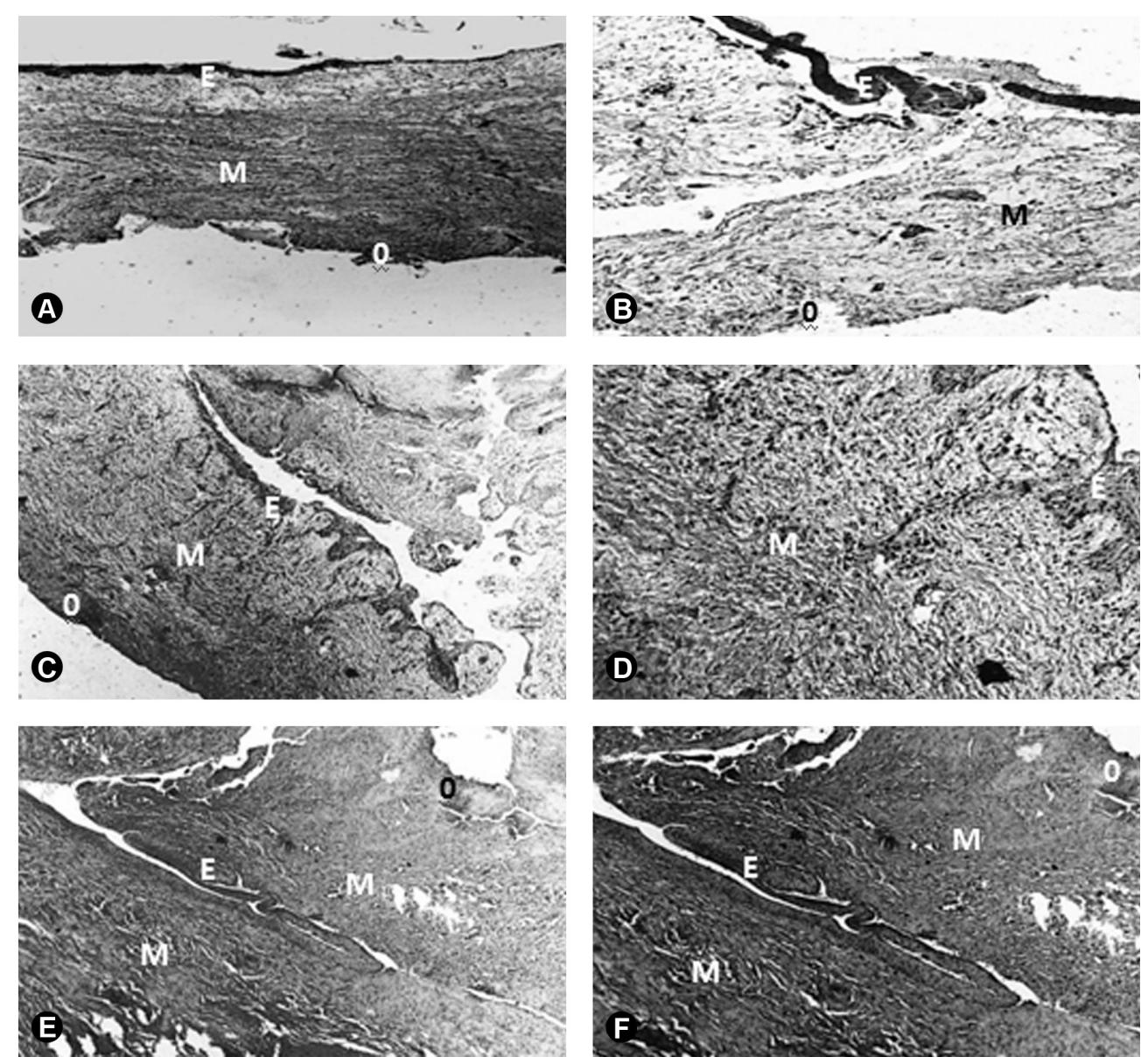

Figure 2. Board of histological slides with the immunostaining for MMP-9 in DC (A and B), RC (C and D) and KCOT (E and F), in 40x and 100x. 
this hypothesis, Silveira et al. (18) report that the strong presence of MMP-9 in the components of mesenchymal KCOTs may explain its aggressive behavior.

In summary, with the exception of MMP-2 and radicular cysts, MMPs are not associated to the area of the lesion. MMP-2 and MMP-9 appear to be related to cystic expansion in DCs and RCs. For these pathological entities, it can be said that smaller lesions are associated to greater bone degradation. In KCOTs, MMP-2 and MMP-9 act in different regions, suggesting that MMP-2 breaks down the basal lamina, allowing tumor invasion and MMP-9 stimulates proliferation and migration, determining the aggressiveness of the disease.

\section{Resumo}

Cistos ósseos uniloculares são as entidades mais comuns que afetam a região maxilofacial. 0 mecanismo de proliferação e expansão permanece obscuro. As metaloproteinases (MMPs) estão associadas a diversas condições patológicas. 0 objetivo do presente estudo foi correlacionar 0 aspecto radiográfico (área) e a presença de MMP-2 e MMP-9 em cistos dentígeros, cistos radiculares e tumores odontogênicos queratocisticos. A área radiográfica de cada lesão foi calculada usando a fórmula matemática da área de elipse. Todas as amostras foram submetidas à análise imunoistoquímica para estas enzimas. A área radiográfica média foi de $284,17 \mathrm{~mm}^{2}, 235,81 \mathrm{~mm}^{2}$ e $381,81 \mathrm{~mm}^{2}$, respectivamente. As análises estatísticas não mostraram associação entre a imunorreatividade de MMPs e área radiográfica das lesões em todas as patologias estudadas, exceto para MMP-2 e cistos radiculares, nas quais as lesões menores tinham maior imunomarcação para esta enzima. Os resultados demonstraram que a quantidade de imunomarcação da MMP-2 e MMP-9 estão envolvidos com cistos dentígeros e radiculares na expansão óssea, ao passo que estas enzimas parecem estar relacionados com o comportamento biológico dos tumores odontogénicos queratocisticos, indicando invasão e proliferação celular. Além disso, há uma relação inversa entre a MMP-2 e MMP-9 em tumores odontogénicos queratocisticos $(p=0,03 ; r s=-0,660)$, indicando atividade em diferentes regiões.

\section{References}

1. Shear M. Cysts of the oral and maxillofacial region - Diagnosis and Treatment. 3rd ed. São Paulo: Editora Santos, 1999.

2. High AS, Robinson PA, Klein CE. Discrimination of parakeratinized odontogenic keratocysts from other odontogenic and non-odontogenic cyst types by expression of a 38kd cell-surface glycoprotein. J Oral Pathol Med 1993:22:363-367.
3. Neville BW, Damm DD, Bouquot JE. Oral and Maxillofacial Pathology 2th ed. Rio de. Janeiro: Guanabara Koogan, 2004.

4. Oliveira MDC, Miranda JL, Amorim RFB, Souza LB, Freitas RA. Tenascin and fibronectin expression in odontogenic cysts. J Oral Pathol Med 2004:33:354-359.

5. Ali MAA. Expression of extracellular matrix metalloproteinase inducer in odontogenic cysts. Oral Surg Oral Med Oral Pathol Oral Radiol Endod 2008:106:258-263.

6. Aumailley M. Structure and supramolecular organization of basement membranes. Kidney Int Suppl 1995:49:S4-S7.

7. Gumbiner BM. Cell adhesion: the molecular basis of tissue architecture and morphogenesis. Cell 1996:84:345-357.

8. Visse $R_{1}$ Nagase $H$. Matrix metalloproteinases and tissues inhibitors of metalloproteinases - Structure, function and biochemistry. Circ Res 2003:92:827-339.

9. Kumamoto H, Yamauchi K, Yoshida M, Ooya K. Immunohistochemical detection of matrix metalloproteinases (MMPs) and tissue inhibitors of metalloproteinases (TIMPs) in ameloblastoma. J Oral Pathol Med 2003:32:114-120.

10. Aimes RT, Quigley JQ. Matrix metalloproteinase-2 is an interstitial collagenase. J Biol Chem 1995:270:5872-5876.

11. Bjorklund $\mathrm{M}$, Koivunen E. Gelatinase-mediated migration in invasion of cancer cells. Biochem Biophys Acta 2005:1755:37-69.

12. Sakamoto $A$, Weinstein $L S$, Plagge $A$, Eckhaus $M$, Kelsey G. GNAS haploinsufficiency leads to subcutaneous tumor formation with collagen and elastin deposition and calcification. Endoc Res 2009:34:12:1-9.

13. Teronen O, Salo T, Konttinen YT, Rifkin B, Vernillo A, Ramamurthy NS, et al.. Identification and characterization of gelatinases/type IV collagenases in jaw cysts. J Oral Pathol Med 1995:24:78-84.

14. Meghji $S$, Henderson $B$, Bando $Y$, Harris $M$. Interleukin-1: the principal osteolytic cytokine produces by keratocysts. Archs Oral Biol 1992:37:935-943.

15. Oka $S$, Kubota $Y$, Yamashiro $T, O$ gata $S$, Ninomiya $T$, Ito $S$, et al.. Effects of positive pressure in odontogenic keratocysts. J Dent Res 2005:84:913918

16. Wahlgren J, Väänänen $A$, Teronen 0 , Sorsa $T$, Pirilä $E$, Hietanen J, et al.. Laminin-5 gamma 2 chain is colocalized with gelatinase-A (MMP-2) and collagenase-3 (MMP-13) in odontogenic keratocysts. J Oral Pathol Med 2003:32:100-107.

17. Miyagi SPH, Hiraki KRN, Martins MD, Marques MM. Expression of matrix metalloproteinases 2 and 9 in odontogenic myxoma in vivo and in vitro. J Oral Sci 2008;50:187-192.

18. Silveira EJD, Piva MR, Galvão HC, Souza LB, Freitas RH. Role of matrix metalloproteinases in the etiopathogeny of odontogenic cysts. J Bras Patol Med Lab 2007:43:203-209. 